\title{
ネパール山岳地帯の伝統的住宅における冬季の温熱環境調査 INVESTIGATION OF WINTER THERMAL ENVIRONMENT IN TRADITIONAL VERNACULAR HOUSES IN A MOUNTAIN AREA OF NEPAL
}

\author{
リジャル ホムバハドゥル*, 吉田治典**, 梅宮典子*** \\ Hom Bahadur RIJAL, Harunori YOSHIDA and Noriko UMEMIYA
}

\begin{abstract}
For the purpose of evaluation and improvement of thermal environment in traditional vernacular houses of Nepal, the winter thermal indoor environment was measured and investigated regarding 1) the relation between indoor and outdoor climate, 2) thermal environmental indices and 3) comparison with existing studies.

1) The thermal environment of investigated houses in ground floors / middle floor are as followings, a) indoor air temp. was $2.5 \mathrm{~K}$ (daytime), $4.7 \mathrm{~K}$ (nighttime) higher than outdoor air temp., b) specific humidity was $0.9 \mathrm{~g} / \mathrm{kg}$ ' (daytime), $1.2 \mathrm{~g} / \mathrm{kg}^{\prime}$ (nighttime) higher than outdoor specific humidity, c) vertical air temp. difference was 3.7K (daytime) greater than the ASHRAE ST-55 thermal comfort standard, that is $3 \mathrm{~K}$, while attic rooms are similar to outdoor. The results showed that the thermal environment are better in ground floors / middle floor than in attic rooms. 2)The mean PMV was -1.2 which was lower than the ISO 7730 standard, that is \pm 0.5 and the mean SET* was $20.0^{\circ} \mathrm{C}$ which was lower than the ASHRAE ST-55, that is $22.2 \sim 25.6^{\circ} \mathrm{C}$. It was clerified that residents live in lower thermal environment than standards. 3) Compared with Japanese houses in existing studies, Nepalese houses were similar in indoor and outdoor temp. differences, while they were less in vertical temp. differences.
\end{abstract}

\section{Keywords:Nepal, Traditional vernacular houses,Indoor and outdoor temp. difference, Vertical temp. difference, Thermal environment, Evaluation ネパール、伝統的住宅、内外温度差、上下温度差、温熱環境、評価}

\section{1. はじめに}

ネパール山岳地帯の伝統的住宅注1) は多くの国の伝統的な住宅と 同様に、内外環境を適切に保ち、環境負荷の少ない環境共生的な建 築形態を経験的に発展させてきた。例えば、1) 冬季の温熱環境に重 点をおいた厚い石造壁の閉鎖的な内部空間、2) 夏季に快適な温熱環 境を得るための木造の開放的な半外部空間、3) 温熱環境を緩和する 外部緩衝空間、4)風向きを考虑した空や住棟配置、5）日射を考慮し た軒の出や屋根形式、6)石、土、草、木などの天然建材を活かした 住宅構法、などがその特徽としてあげられる。

しかしながら、住宅の内部空間は、特に冬季において、空ガラス や閉鎖用の戸もなく、半外部空間に似た開放的空間が多いため、な お解決すべき問題も多い。例えば、1) 冬季には室内は寒冷で、高龄 者の死亡率が高いといわれている。2)大量の菥注2〕燃やしている が、隙間の多い開放的空間で快適な温熱環境が得られず、暖房の効 率も空間的温度分布も悪い。また、薪による煙の処理と気密性の兼 ね合いが難しい。3）土間に素足で生活するため、低温な床表面温が 不快と思われている。4）また、最近の技術や材料が安易に採用さ れ、例えばトタン屋根注3)のように、その急激な表面温度変化が室 内環境を悪化させている。

従来、ネパールの伝統的住宅に関する研究は、建築計画学や文化
人類学的観点から行われてきた。それらはネパール各地の伝統的集 落における空間構成、構法、住み方を分析した研究 ${ }^{1) 〜 4) 、 カ ト マ ~}$ ンズ盆地の伝統的住宅、寺院、王宮、広場、中庭、仏教建築の空 間構成を分析した研究 5)、8)などに限られ、環境工学的視点からの研 究は皆無で温熱環境の実態は明らかではない。また、ネパール山岳 地帯では普通、直火の炉が使用されているが、日本の伝統的住宅の 研究は、建築構成要素と室内温熱環境の関係を明らかにしながら、 開放型ストーブ、電気こたつ、石油ストーブ、扇風機、煙突薪ストー ブ、ルームクーラーのような暖冷房設備に関連付けた研究が多く7) 〜9)、薪燃焼に関連付けた研究は、アイヌ伝統住居チセを復元して

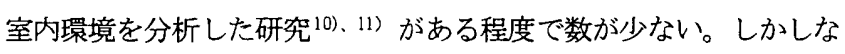
がら昨今、ネパールにおいても冬季の暖房や調理のためのエネル ギ一使用の増大に伴う、森林の枯渴、直火の使用による室内空気污 染の改善など、環境やエネルギ一問題が徐々に顕在化しており、煙 突付炬の推奨、森林伐採の抑制、植林などの環境改善政策が行われ 始めていることから、伝統的住宅の環境をネパールの社会に即した 形で、いかにして適切に改善してゆくかという視点の研究が不可欠 である。

本論文では、ネパールの代表的な山岳地帯の伝統的住宅を取り上 げ、冬季の温熱環境を実測し、1) 住宅における内外温湿度差、上下

\footnotetext{
* 京都大学大学院工学:研究科環境地球工学尃攻 博士課程·工修

** 京都大学大学院-上学研究科環境地球工学尃攻 教授・工博

*** 大阪市立大学大学院工学研究科建筑学尃攻 講師 - 工博
}

Graduate Student, Dept. of Global Environment Eng., Faculty of Eng., Kyoto University, M. Eng.

Prof., Dept. of Global Environment Eng., Faculty of Eng., Kyoto University, Dr. Eng.

Lecturer, Dept. of Architecture and Building Eng., Osaka City University, Dr. Eng. 


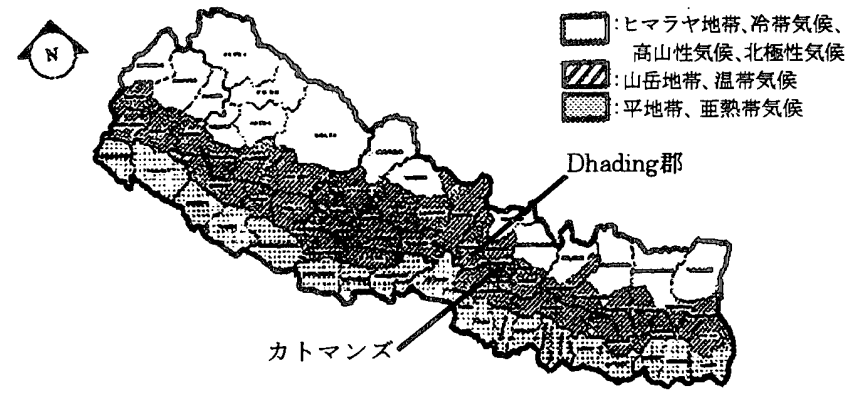

図 1 調查対象地域の地形々気候の位置付け

温度差など、その熱的特性を定量的に把握し、2)PMV、SET*などの温 熱環境指標によりその温熱環境を評価し、3）日本の伝統的住宅と比 較し、4) 改善案を示した結果を報告する。

\section{2. 対象地域の概要}

ネパールは東経 $80^{\circ} 4^{\prime} \sim 88^{\circ} 12^{\prime}$ 、北緯 $26^{\circ} 22^{\prime} \sim 30^{\circ} 27^{\prime}$ に位 置し、国土面積は $147,181 \mathrm{~km}^{2}$ 、東西の長さは約 $800 \mathrm{~km}$ 、南北の幅は約 $160 \mathrm{~km}$ と東西に細長く南北に短い国である ${ }^{12)}$ 。南北の標高差が非常に 大きく、この差により様々な内陸気候が形成されている。つまり、南 部の平地帯は亜熱帯気候、中部の山岳地帯は温帯気候、北部のヒマ ラヤ地帯は冷帯気候、高山性気候、北極性気候に分類できる(図 1)。 人々は海抜約 $50 \mathrm{~m} \sim 5769 \mathrm{~m}$ までの広範囲に住んでおり、地域によっ て様々な伝統的住宅がみられる13)。本論文の調查対象地域は中央ネ パールの海拔約 $1500 \mathrm{~m}$ の Dhading 郡 Jyamrung 区 Salle村である（図 1、写真 1)。Salle 村の選定理由は、ネパール山岳地帯の典型的な村 であること注 4)、1996 年に集落調査が行われ、建築計画的な特徴が 判っていることにある3)。郡内の気象台で 1994 年に観測された月別 平均気温の最低は 1 月で $12.9^{\circ} \mathrm{C} 、$ 最高は 7 月で $26.1^{\circ} \mathrm{C} 、$ 月別平均相対 湿度の最低は 1 月で $73 \%$ 、最高は 8 月で $86 \%$ である ${ }^{14) 。 ~}$

\section{3. 調査対象住宅の概要 3 )、4)}

\section{1 空間構成}

この地域の住宅構造は2、3 階建ての草草き住宅、石板亘き住宅が 一般的であるが、ここ 20 年は施工性と耐久性の観点からトタン蕞き 住宅も建てられつつある。調査対象住宅として典型的なa) 石板葺き 住宅、b) 草莫き住宅、c) トタン莫き住宅の 3 軒を選んだ（図 2)。こ れらは南斜面に建っており、母屋、前庭, 畜舎兼住居, 畜舎、蒠置 き場からなっている。この村では、南斜面の場合は谷側を住宅の正 面に，北斜面の場合は西や東を正面にする場合が多い。住宅の空間 は、内部空間、半外部空間、外部空間の 3 つに分類できる。内部空 間とは石造の壁で囲まれた空間をいう。閉鎖的な内部空間は暖かく、 冬季を過ごすのに適している。室内には間仕切がないが、1階は宗教 的理由から $10 \mathrm{~cm}$ 程度の段差が設けられ下座と上座に分かれている。 天井高が低く(約 $1.6 \mathrm{~m})$ 、上下階を鶖ぐ階段部分は吹抜になっている。 半外部空間は内部空間の外側で、石造壁体に接した木造で開放的な 外部空間をいう。1 階はピロティ的で，平面的にはL字型に配置され ることが多い。半外部空間の 1 階を「軒下」、2階を「バルコニー」と 呼ぶことにする。軒下には縁台，踏台，石田，槌，鷄小屋等が置 かれており、日常作業、日光浴、日陰での休壿、来客の出迎え，夏 季の就寝などに利用される。バルコニ一の両端にはベッド付きの部 屋（以下バルコニー部屋と呼ぶ）が設けられる場合が多い。バルコ

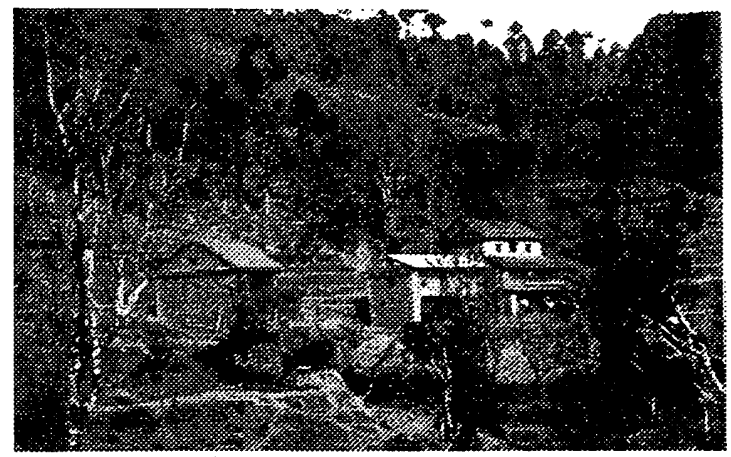

写真 1 Salle 村の全体像

山のほぼ頂上にある南斜面の段々㚼に建つ、左から草葛き住 宅、トタン葛き住宅と石板菖き住宅である。
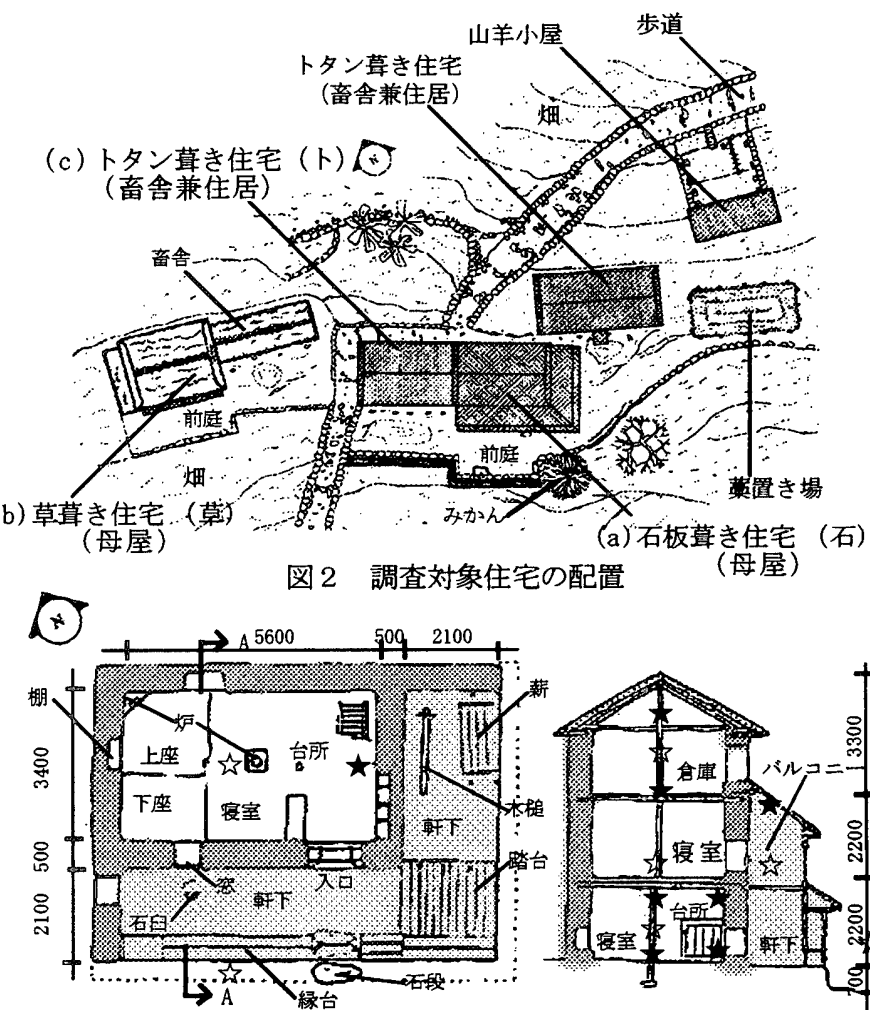

（a）石板荣き住宅の 1 階平面図と A-A 断面図

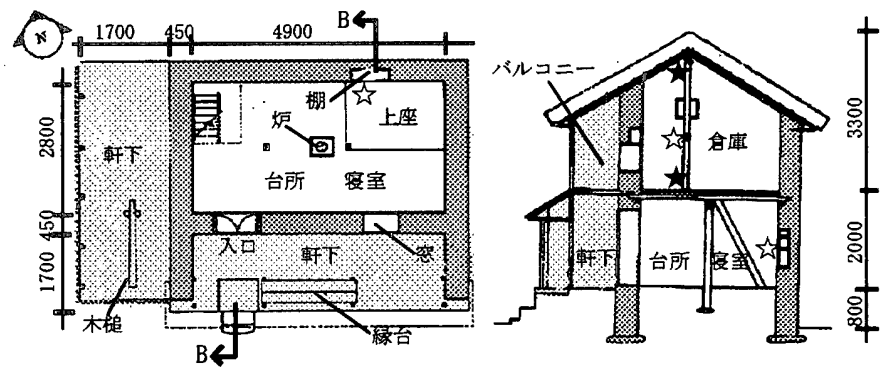

（b）草蓄き住宅の 1 階平面図と B-B 断面図

(*)

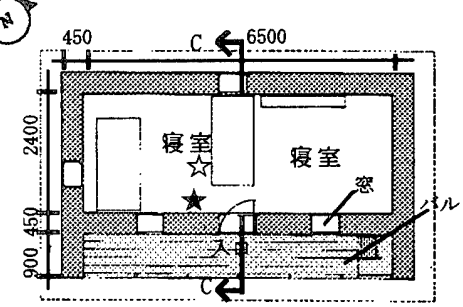

（c）トタン莫き住宅の 2 階平面図と C-C 断面図

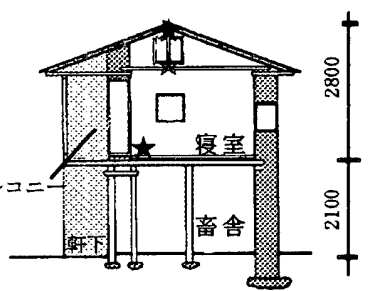

図 3 調查対象住宅の平面図と断面図 
表 1 調查対象住宅の概要

\begin{tabular}{|c|c|c|c|}
\hline 检討唄自 & a)石板萛き住宅 & b)草算き住宅 & c)トタン其き住宅 \\
\hline 階数 & 3 & 2 & 2 \\
\hline 壁体楆造 & 石造 & 石造 & 石造 \\
\hline 屋根 & 切素、石板龩 & 切妻、草蒠き & 切妻、トタン堇き \\
\hline 笑年 & 15 & 3 & 4 \\
\hline 丙部延床面艘 $\left[\mathbb{m}^{2}\right]$ & 57.1 & 27.4 & 31.2 \\
\hline 半外部延原面积 $\left[\mathrm{m}^{2}\right]$ & 48.8 & 28.0 & 11.7 \\
\hline 世蒂人数 & 9 & 7 & $2^{*}$ \\
\hline
\end{tabular}

ニーの手摺りは透かし彫りでデザインされており，洗濯物を干した り，野菜や果物を乾燥させるのに用いられる。開放的な半外部空間 は涼しく、夏季を過ごすのに適している。外部空間は前庭であり、母 屋、畜舎兼住居、畜舎などを相互に慗ぐ役割を持っており、日常作 業、款物の乾燥、日光浴、祭礼や宗教儀式などに利用される。

\section{2 構法}

全ての住宅の壁は厚さ約 $50 \mathrm{~cm}$ の石造であり、厚さ約 $20 \mathrm{~cm}$ の石を厚 さ約 $5 \mathrm{~cm}$ の粘土で接合して、内外から粘土を叙って仕上げる。接地 階の床は厚さ約 $50 \mathrm{~cm}$ の粘土を固めて造る。天灭井は大梁、小梁を組み， その上に長さ約 $50 \mathrm{~cm}$ 厚さ約 $5 \mathrm{~cm}$ の木材を隙間なく敷き詰め、更にそ の上に厚さ約 $20 \mathrm{~cm}$ の粘土で固めて造る。空枠は木製で、ガラスは使 用されていない。窓には、透かし彫り空（空枠に繸長の棒や幾何学 的模様を格子状に入れた戸のない空)、戸付き空(開閉戸が付いてい る空)、開放空（全面が開放された空）がある。空は南面に多く、最 上階を除き、北面と東西面には空がない。屋根は、木造小屋組みの 上に石板、草、トタンで幕かれている。

\section{3 住宅の種類 (表 1、表 2)}

\section{3.1 石板草き住宅 (図 $3(\mathrm{a})$ )}

3 階建ての石板幕き住宅は、東と南にL 字型の半外部空間を有す る。1 階は台所兼居間兼寝室, 2 階は寝室兼倉庫、3 階は倉庫として 利用されている。1階と 2 階の南にドア (各 1)、1 階の南に透かし彫 り空 $\times 1 、 2$ 階の南に戸付き空 $\times 1 、 3$ 階の南に透加し彫り空 $\times 2 、$ 一 付き空 $\times 1$ 、東に戸付き空 $\times 1$ 、小屋組み内の東西に開放空 (各 1$)$ が 設けられている。バルコニ一部屋の東と南面の壁は木板張り、北と 西面は石造である。木板镸り壁に恃透かし彫り空とドアがあり、木 板床と木板張り壁には多くの隙間がある。1 階と 2 階は開口部が少な い気密性の高い閉鎖的な空間であるが、3 階と半外部空間は開口や隙 間が多く、気密性の低い開放的な空間となっている。屋根は、木造 小屋組みの上に 約 $20 \mathrm{~cm} \times 20 \mathrm{~cm} \times 1 \mathrm{~cm}$ の石板で幕が、釷で固定し てある。石板莫き屋根には土、木版の断熱性の材料を使用しておら ず、屋根、屋根と石造壁の間には隙間があいている。

\section{3.2 草苜き住宅 (図 3(b))}

2 階建ての草草き住宅は、西と南にL 字型の半外部空間を有する。 1 階は台所兼居間兼寝室、2 階は倉庫兼寝室、バルコニーは寝室とし て利用される。1階と 2 階の南側に透かし彫り空とドア（各1）、2階 の小屋組み内の東西に開放空（各 1）があり、1階は開口部の少ない 閒鎖的な、二階は開口部の多い開放的な空間である。屋根は木造小 屋組みに長さ約 $80 \mathrm{~cm}$ の細長い草を厚さ約 $50 \mathrm{~cm}$ にヒモで結んで㷬く。 草楞き屋根は通常 $3 \sim 4$ 年ごとに菖きかえられる。

\section{3. 3 トタン苴き住宅（図 $3(\mathrm{c})$ )}

トタン莫き住宅は 2 階建てで、 1 階は水牛と山羊小屋、 2 階は寝室 で、石板莫き住宅の畜舎兼住居となってている。1階は南に壁がなく、 可動式の壁（葉付きの枝で作った軽い壁）によって昼夜で日射、冷 気、通風などを調整する。2階の南にドア $\times 1 、$ 透かし彫り空 $\times 2 、$ 西と北に透かし彫り窓(各 1$) 、 小$ 屋組み内の西に開放空 $\times 1$ が設けら
れ、開口部の多い開放的空間である。屋根俚木造小屋組みに約 $1 \mathrm{~m} \times$ $2 \mathrm{~m}$ の塗装していないトタンを荤く。トタン屋根に土、木版の断熱性 材料は使用されず、屋根と石造壁の間に隙間があいている。

\section{4 居住者の生活署面}

冬季の一日の主な生活パターンや空間利用はおよそ、6〜8 時頃 に内部空間で薪然焼による採暖、8〜12 時頃に前庭で日光浴、12〜 17 時頃に半外部空間で日光浴や日陰で休䕀、17〜21 時頃に内部空 間で採暖、夜に内部やバルコニー部屋で就蔓、のようになっている。 朝食は $6 \sim 9$ 時頃、昼食は $14 \sim 15$ 時頃、夕食は $18 \sim 20$ 時頃、家畜 の餌は $20 \sim 21$ 時頃に調理する。調理と採暖の時間帯が重なること で、ある程度薪が節約されている。1999 年 12 月の平均薪消費量は石 板莫き住宅で $11.4 \mathrm{~kg}$ 、草草き住宅で $8.5 \mathrm{~kg}$ であった。薪は近くの山 から採取され、1〜2ケ月乾嬠された松などの木材である。土間の表 面温度は低いが、一般的に宗教的な理由で住居内では裸足で過ご す。戸付き空は昼間は開け夜間は閉め、透加彫り空や開放空は賟 マットで塞ぐことが多い。村人は日々忙しく、大人は烟仕事、家畜 の草刈、家畜の放牧に出汃忛、子供は学校に行き、幼い子供や老人 は留守番することが多い。

\section{4. 測定概要}

\section{1 測定日時}

調查期間は 1998/12/19〜 21 で、天候は冬季として代表的で、19日 と 20 日は晴天、21 日は晴れ時々最りであった。なお、外気温湿度、 風向風速、日射量の測定は、19日の 12:00〜20日の 16:00に行った。

\section{2 測定項目および方法}

温熱環境の測定は、表 3 に示す機器を用いて、外部環境（温湿度、 日射量、風向風速）と内部環境（温湿度、グローブ温度）を、図 3 と表 4 に示す位置で行った。日射量と風向風速は、石板莫き住宅か ら南へ約 $25 \mathrm{~m}$ 離れた障害物のない地上 $1.5 \mathrm{~m} て ゙$ 測定した。外気温湿度 は石板葺き住宅の前庭の地上 $1.5 \mathrm{~m}$ で、日射の影響を避けて測定し た。半外部空間と内部空間の温湿度は、各室のほぼ中央の床上 $0.1 \mathrm{~m}$ (以下、床付近と呼ぶ)、中央部、天井下 $0.1 \mathrm{~m}$ (以下、天井付近と呼 ぶ)、屋根裏下 $0.1 \mathrm{~m}$ (以下、屋根裏付近と呼ぶ）で測定した。グロー ブ温度は、石板雚き住宅の 1 階床上 $0.8 \mathrm{~m}$ で測定した。測定値は全て 5 分間隔でデータロガーに記録した。

\section{3 測定データの校正と奶理}

機種による測定誤差を除くために、風向計を除く全ての測定機器 は、人工気候室内で調查前後に校正した。また、風向を除く全ての 測定データは、変動の緩やかなデータを得るために、ローパスフィ ルターで処理した。

\section{5. 結果と分析}

表 4に、晴天日である 19(12:00) 20 日 (12:00)の外部、接地階/中 間階と屋根裏の温湿度測定結果を示す。昼間とは 6:00〜18:00を、 夜間とは $18: 00$ 翌朝 6:00を指す。 
表 4 石板莫き、草莫きとトタン莫き住宅の接地階/中間階と屋根裏の温湿度、内外温湿度差と上下温度差

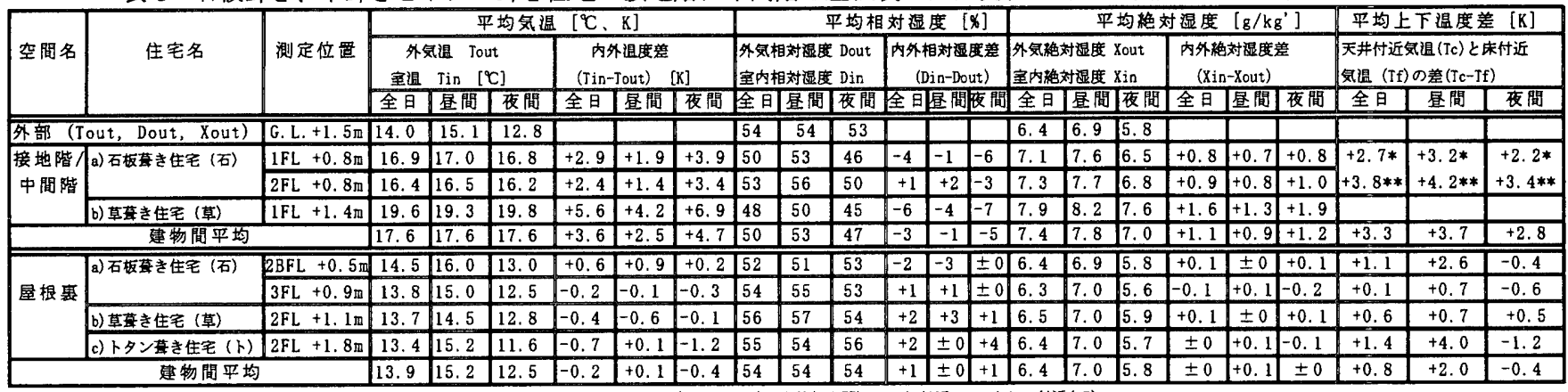

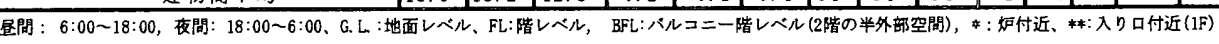

\section{1 外部環境と住宅計画の関係}

正面である南側に前庭、東と南側に半外部空間を設け、南側の 多くの開口部を開放し、東西や北側を石造壁で閉鎖することで、昼 間の日射を確保して、昼間の温風を建物に導入し、夜間は冷風を避 けるといった、温熱環境的工夫がみられる。冬季は快晴日が多く、 分析対象日の最大日射量は $595 \mathrm{~W} / \mathrm{m}^{2}$ であることから、昼間、居住者 は日当たりの良い前庭や軒下で生活していた。また、風向風速は昼 間平均で南風 (谷風) $1.3 \mathrm{~m} / \mathrm{s}$ 、夜間平均で北風（山風） $0.8 \mathrm{~m} / \mathrm{s}$ であ り、昼間は暖められた温風が谷風で室内に運ばれて室内が暖められ るように、夜間は風速が弱く建物の背面（北側）に空がないため夜 間の北風が建物の中に入って熱を奪うのを抑えるように計画されて いるといえる。

\section{2 接地䀝/中間階と屋根裹の温熱環境比較}

室内温熱環境分析は各建物の接地階/中間階、屋根裏の内外温湿 度差と上下温度差で比較する。これは、両者の接地階/中間階と屋 根裹に空間ならびに生活習慣上の類似性があるためである。接地階」 とは石板莫き住宅（石 $1 F ）$ と草莫き住宅の 1 階（草 $1 F$ ）を、中間階] とは石板莫き住宅 2 階（石 $2 F$ )、屋根裏」とは石板葷き住宅のバルコ 二一部屋（石 $2 \mathrm{~B} ）$ と 3 階（石 $3 \mathrm{~F}$ )、草莫き住宅とトタン莫き住宅の 2 階（草 $2 F$ とト $2 F ）$ を指す。

図 4 に接地階 / 中間階の、図 5 に屋根裹の温熱環境をまとめて示 す。凡例は各図の下に示した。図4(a)、図 5 (a)に室温(Tin) と外気温 (Tout)の時刻変化を示す。

分析期間中の日平均気温（日平均相対湿度）は、外気が $14.0^{\circ} \mathrm{C}$ (54\%RH)、接地階/中間階は建物間で $16.4^{\circ} \mathrm{C}(48 \% \mathrm{RH}) \sim 19.6^{\circ} \mathrm{C}(53 \% \mathrm{RH})$ 、 屋根裏は $13.4^{\circ} \mathrm{C}(52 \% \mathrm{RH}) \sim 14.5^{\circ} \mathrm{C}(56 \% \mathrm{RH})$ であった。接地階の日

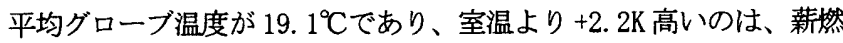
焼の影響と思われる。

\subsection{1 内外温度差}

図 4(b)、図 5(b)に室温(Tin) と外気温(Tout) の内外温度差(Tin-Tout) の時刻変化を示す。平均值は表 4 に示す。また、図 4 (c)、図 5 (c) に は同一時間帯の室温と外気温の相関を示す。

接地階 / 中間階の内外温度差（内-外）は、建物間平均で昼間平 均 $+2.5 \mathrm{~K}$ 、夜間平均 $+4.7 \mathrm{~K}$ で、夜間の方が大きく、昼夜とも内部が外 部より高い。これは、1)昼間にドアと空を開放して通風し、夜間には ドアと空を閉めて冷気浸入を避けていること、2）朝晚の寒い時間帯 に薪を燃やしていること、3）開口部（ドアと空）が少ない閉鎖的な 空間であること、4) 熱容量の大きい石造壁による蓄熱効果などが考 えられる。石板蕞き住宅の中間階が接地階と似た室温になっている
のは、接地階と同数の開口部があり、階段吹拔により接地階と一体 化した空間になっているためと思われる。

屋根裏の内外温度差（内-外）は、建物間平均で昼間平均 $+0.1 \mathrm{~K}$ 、 夜間平均 $-0.4 \mathrm{~K}$ で夜間は外部より低い。昼間に外部より低いのは、石 板莫き 3 階 $(-0.1 \mathrm{~K})$ と草草き住宅 $(-0.6 \mathrm{~K})$ 、夜間に外部より低いのは石 莫き 3 階 $(-0.3 \mathrm{~K})$ 、草草き住宅 $(-0.1 \mathrm{~K})$ とトタン苟き住宅 $(-1.2 \mathrm{~K})$ であっ た。接地階 / 中間階の内外温度の相関係数は $0.22 \sim 0.84$ であること に比べて、屋根裏の相関俰数 $0.89 \sim 0.98$ の方がかなり高く、屋根裏 の方が外気温の瞬時的な影響が大きい(図 $4(\mathrm{c})$ 、図 5(c))。屋根裏が 昼夜とも外部に近い室温になっているのは、1) 空が一日中開放され ていること、2）開口部が多い開放的な空間であること（石板莫き住 宅 3 階では 6 つの空と階段吹抜、草蕞き住宅では 3 つの空・ドア・階 段吹抜、トタン莫き住宅では 5 つの空・ドアがある)、3）屋根が断熱 されておらず多くの隙間があること、4)バルコニ一部屋の板張り壁 に多くの隙間があることなどが理由と考えられる。

以上をまとめると、接地階/中間階の内外温度差は屋根裏より昼 間 $2.4 \mathrm{~K}$ 、夜間 $5.1 \mathrm{~K}$ 大きい。これは接地階では薪燃焼による採暖や開 口部開閉などの生活習慣、外気侵入を防止する閉鎖的空間といった 内外温度差を高める工夫がなされているが、屋根裏では生活時間が 短いことから、開口部開閉の生活習慣がなく、外気変動に左右され る開放的空間になっているためと考えられる。

\subsection{2 内外絶対湿度差}

図 4(d)、図 5(d) に室内絶対湿度 (Xin) と外気絶対湿度 (Xout) の内外 絶対湿度差(Xin-Xout) の時刻变化を示す。平均值は表 4 に示す。ま た、図 $4(\mathrm{e})$ 、図 $5(\mathrm{e})$ には同一時間帯の室内絶対湿度と外気絶対湿度 の相関を示す。

接地階/中間階の平均内外絶対湿度差（内－外）は、建物間平均 で昼間平均 $+0.9 \mathrm{~g} / \mathrm{kg}^{\prime}$ 、夜間平均 $+1.2 \mathrm{~g} / \mathrm{kg}$ 'で、夜間の方が大きい。 昼夜とも内部が外部より高いのは、炊事による水蒸気発生、土間、 土壁からの水蒸気放出などの影響と考えられる。

屋根裏の内外絶対湿度差 (内-外) は、建物間平均で昼間平均 $+0.1 \mathrm{~g} /$ $\mathrm{kg}$ 、夜間平均 $\pm 0.0 \mathrm{~g} / \mathrm{kg}^{\prime}$ で昼間に外部より湿度が高いがそのオ一 ダーが小さく、昼夜とも建物によって異なるが、その差異は顕著で はない。これは、開口部や隙間に多大な漏気があるためと考えられ る。接地階/中間階の内外絶対湿度の相関係数 $0.82 \sim 0.99$ 上りも屋 根裏の相関係数 $0.98 \sim 0.99$ の方が僅かに高く、屋根裹の方が多少空 気の出入りが多いことが推察される(図4(e)、図5(e))。なお、日平 均内外相対湿度差(Din-Dout) 梳、接地階 / 中間階では-3\%RH で外部よ ク内部の方が低いのに対して、屋根裏では内部が $+1 \% R H て ゙$ 外部より 


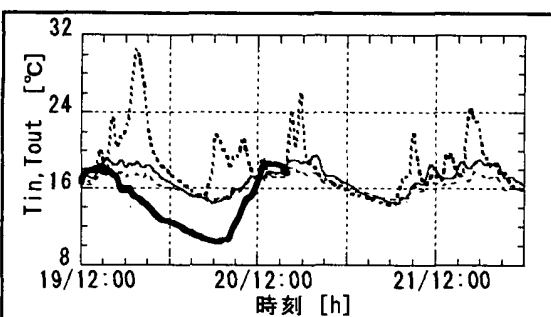

(a) 外気温と空温

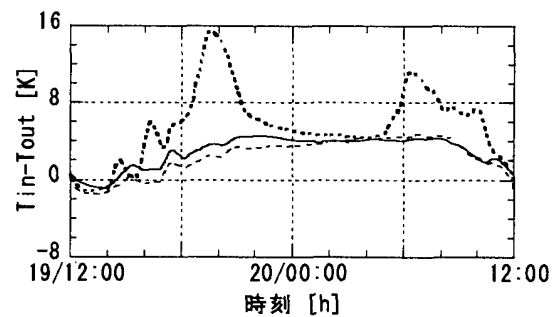

(b) 内外温度差

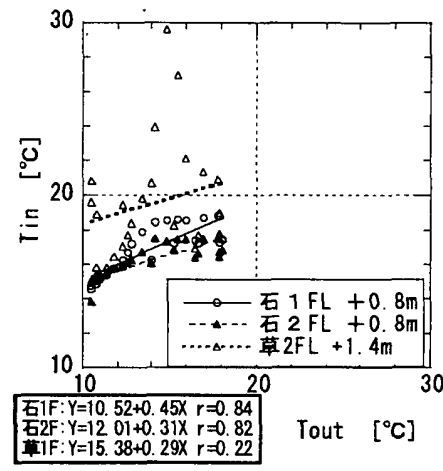

(c) 内外温度の相関

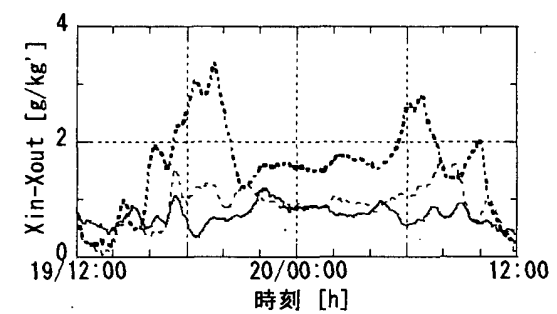

（d）内外絶対湿度差

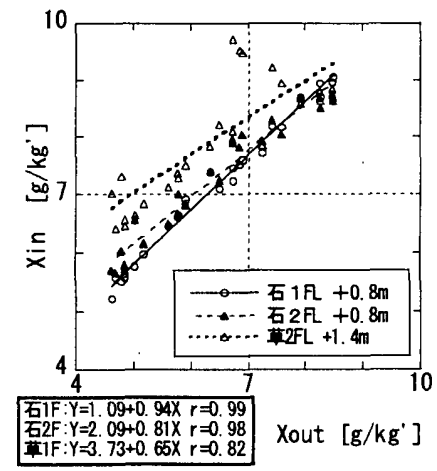

（e）内外絶対湿度の相関

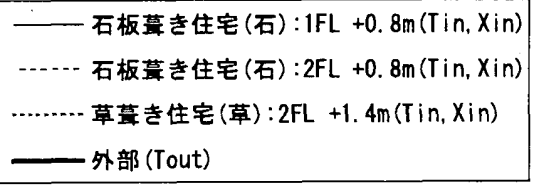

図 (a)，(b)，(c)，(d)，(e)の凡例

図4 接地階/中間階の温熱環境

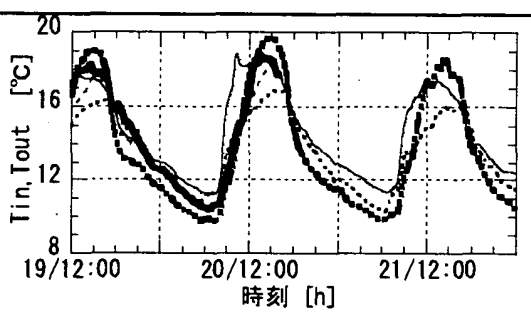

(a) 外気温と室温

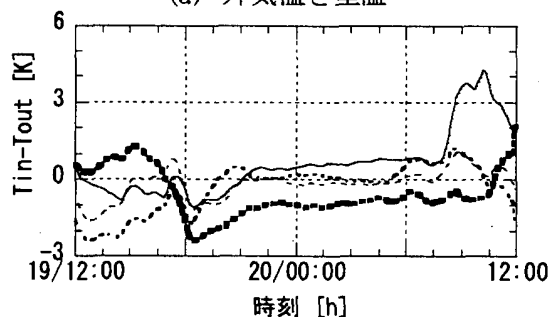

(b) 内外温度差

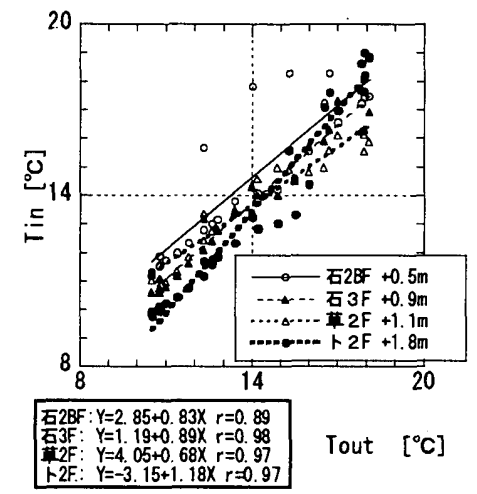

(c) 内外温度の相関

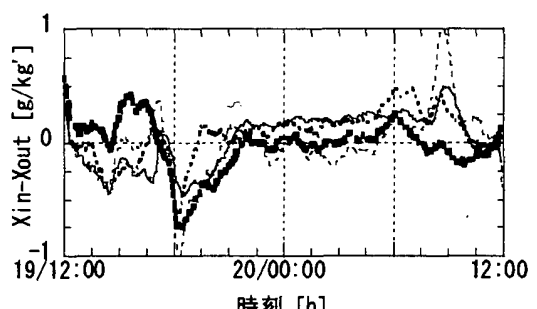

（d）内外絶対湿度差

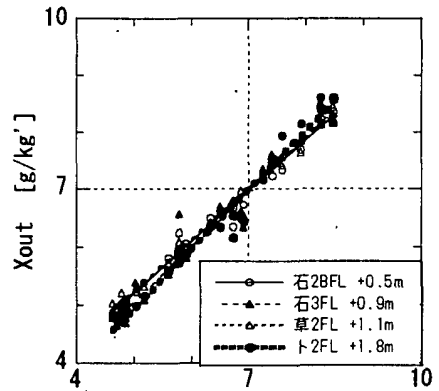
吾政: $Y=0.83+0.87 \times \quad Y=0.99 \quad$ Xout $\left[\mathrm{g} / \mathrm{kg}^{\prime}\right.$ F. $y=-0.15+102 x \quad r=0.99$

(e) 内外絶対湿度の相関

石板革き住宅(石):2BFL +0.5m (Tin, Xin)

石板晜き住宅 (石) : $3 F \mathrm{~L}+0.9 \mathrm{~m}(\mathrm{Tin}, X i n)$

草覃き住宅 (草) $: 2 \mathrm{~F}+1.1 \mathrm{~m}(\mathrm{Tin}, \mathrm{X}$ in)

トタン菖き(ト):2F +1.8m(Tin, Xin) 外部 (Tout)

図 (a), (b), (c), (d), (e)の凡例

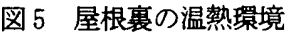

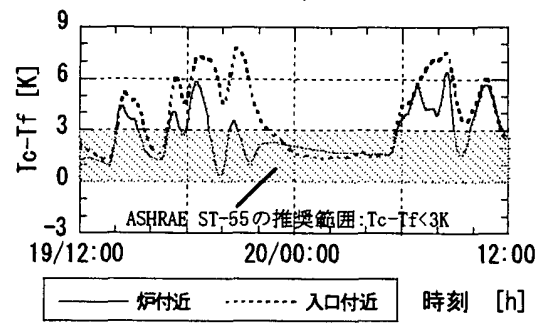

図 6 石板葺き住宅接地階の上下温度差

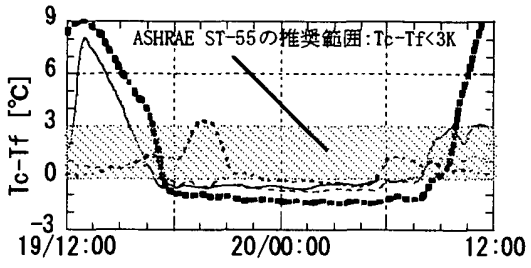

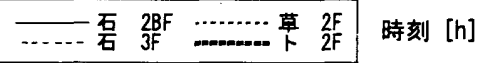

図 7 屋根裹 $の$ 上下温度差

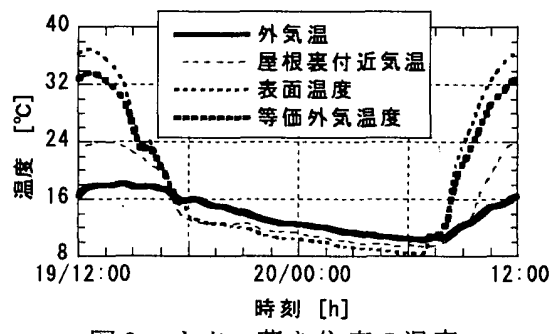

図 8 トタン葺き住宅の温度

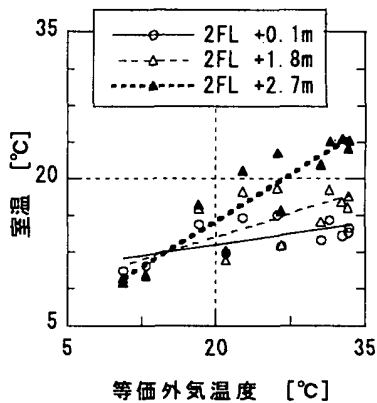

$+0.1 \mathrm{~m}: Y=10.28+0.14 X \quad r=0.62$ $+1.8 \mathrm{~m}: Y=7.65+0.31 X \quad r=0.73$
$+2.7 \mathrm{~m}: Y=3.16+0.62 X \quad r=0.91$

図9 トタン葺き住宅の室温と等価外気温の相関

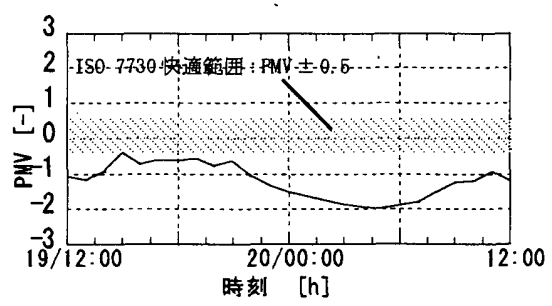

図 10 石板葺き住宅接地階の PMV

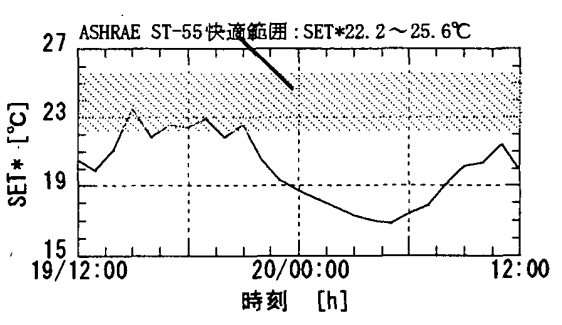

図 11 石板菆き住宅接地階の SET* 
高いが差は僅かであり、内外差はないといえる。

以上をまとめると、接地階/中間階の内外絶対湿度差は、内外温 度差と同様に屋根裏より大きく、屋根裏より昼間で $0.8 \mathrm{~g} / \mathrm{kg}$ 、夜間 で $1.2 \mathrm{~g} / \mathrm{kg}$ '大きい。これは、接地階では炊事や生活者からの水蒸気 発生があり、屋根裏では開口部や隙間から外気の継続的な流入があ るためと考えられる。

\subsection{3 上下温度盖}

図 6 に石板莫き住宅の接地階、図 7 に屋根裹の天井付近気温 $(\mathrm{Tc})$ と 床付近気温 (Tf)の上下温度差(Tc-Tf) の時刻変化を示す。平均值は表 4 に示す。

石板葺き住宅の接地階の平均上下温度差 (上-下) は、昼間平均 $+3.7 \mathrm{~K}$ より夜間平均 $+2.8 \mathrm{~K}$ のほうが小さい。昼間に炉で薪を燃焼させ 炊事や採暖が行われ、発生熱が天井付近に溜るためと考えられる。

屋根裹の平均上下温度差は、建物間平均で昼間平均 $+2.0 \mathrm{~K}$ 、夜間平 均-0.4Kで、夜間の方が小さい。草莫き屋根は断熱性が高いため尽 夜とも殆ど差がなく、日平均上下温度差は $0.6 \mathrm{~K}$ であった。しかし、 トタン蕞き屋根の平均上下温度差は昼間で $+4.0 \mathrm{~K}$ 、夜間で $-1.2 \mathrm{~K}$ であ る。これは石板幕き住宅 3 階より昼間で $3.3 \mathrm{~K}$ 大きく、夜間で $0.6 \mathrm{~K}$ 小 さい。接地階炉付近の昼間平均 $+3.2 \mathrm{~K}$ 、入り口付近の昼間平均 $+4.2 \mathrm{~K}$ と夜間平均 $+3.4 \mathrm{~K}$ 、トタン蕞き住宅の屋根裏の昼間平均 $+4.0 \mathrm{~K}$ は、

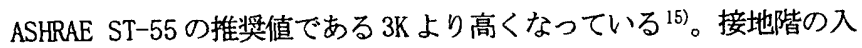
口付近は開放的、炉付近は閉鎖的な空間であることから、入口付近 の上下温度差は、昼夜とも炉付近の上下温度差より大きい。

以上をまとめると、接地階の上下温度差は、内外温湿度差と同様 に屋根裏より大きく、屋根裹より昼間 $1.7 \mathrm{~K}$ 、夜間 $3.2 \mathrm{~K}$ 大きい。これ は接地階では開放型炉で薪燃焼による内部発熱があり、平面や断面 の狭い部屋で部分的に閉鎖的になっているのに対して、屋根董では 内部発熱がなく、開放的空間になっているためと考えられる。接地 階の上下温度差が推奖值より大きいことは、不快な温熱環境と薪で 発生する熱の浪費の可能性を示している。

\section{3 屋根材の室温への影響}

トタン莫き屋根の熱性状を把握するために、日射や放射の効果を 加味し、定常熱バランス式に基づいて等価外気温度と表面温度を算 出した。計算条件は、トタン屋根の日射吸収率と放射率を 0.65 と 0.30 とし、屋根外側の熱伝達抵抗を $0.05 \mathrm{~m}^{2} \mathrm{~h}^{\circ} \mathrm{C} / \mathrm{kcal}$ とした。

図 8 にトタン屋根の屋根裏付近気温、表面温度、等価外気温度の 時刻変化、図 9 に等価外気温度と室温の相関を示す。

トタン苟き屋根は日射の影響で昼間の室温が外気温より高く、夜 間放射冷却の影響で夜間は外気温より低い。気温は、昼間は屋根裏 付近ほど高く、夜間は屋根裏付近ほど低い。すなわち、昼間の平均 室温は、床付近 $13.8^{\circ} \mathrm{C} 、$ 中央部 $15.2^{\circ} \mathrm{C} 、$ 屋根裹付近 $17.8^{\circ} \mathrm{C}$ であり、 外気との差はそれぞれ-1.3K、+0.1K、+2.7Kであった。屋根亭付近の

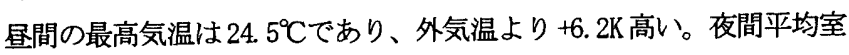
温は、床付近 $12.4^{\circ} \mathrm{C}$ 、中央部 $11.6^{\circ} \mathrm{C}$ 、屋根稁付近 $11.2^{\circ} \mathrm{C}$ であり、外 気温よりそれぞれ $0.4 \mathrm{~K} 、 1.2 \mathrm{~K} 、 1.6 \mathrm{~K}$ 低い。屋根裏付近の夜間最低気

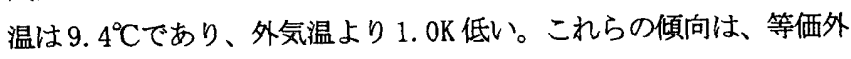
気温度が最高 $33.7^{\circ} \mathrm{C}$ 、表面温度が最高 $36.9^{\circ} \mathrm{C}$ 、最低 $8.2^{\circ} \mathrm{C}$ という計算 結果とも一致している。床付近、中央部、屋根裏付近の室温と、等 価外気温度の相関係数は、それぞれ $0.62 、 0.73 ， 0.91$ となり、トタ ン屋根に近いほど相関が高いという結果となった。
石板草き屋根は日射による温度上昇が殆どみられなかったが、夜間 放射冷却による温度低下がみられた。石板莫き住宅 3 階の昼間平均室

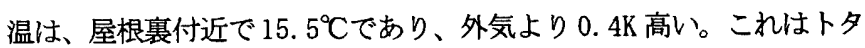

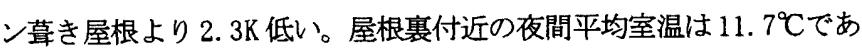
り、外気温より $1.1 \mathrm{~K}$ 低い。これはトタン莫き屋根より $0.5 \mathrm{~K}$ 高い。ま た、屋根裏付近の夜間最低気温は $9.6^{\circ} \mathrm{C}$ であり、外気温より $0.8 \mathrm{~K}$ 低い。 これはトタン蒙き屋根より $0.2 \mathrm{~K}$ 高い。

草草き屋根は日射や夜間放射冷却による温度上界や低下がなかっ

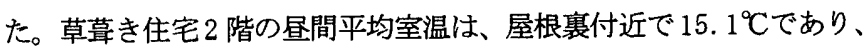
外気温との差はないといえる。これはトタン圌き屋根より $2.7 \mathrm{~K}$ 低く、 石莫き屋根より $0.4 \mathrm{~K}$ 低い。屋根寒付近の夜間平均室温は $13.4^{\circ} \mathrm{C}$ であ り、外気温より $0.6 \mathrm{~K}$ 高い。これはトタン莫き屋根より $2.2 \mathrm{~K}$ 高く、石 板蕞き屋根より $1.7 \mathrm{~K}$ 高い。また、屋根裹付近の夜間最低気温は 10.6 ${ }^{\circ} \mathrm{C}$ であり、外気温より $0.2 \mathrm{~K}$ 高い。これはトタン蒙き屋根より $1.2 \mathrm{~K}$ 高 く、石板屋根より $1.0 \mathrm{~K}$ 高い。

以上をまとめると、草莫き屋根の屋根裏付近の平均気温は、石板草 き屋根より尽間で $0.4 \mathrm{~K}$ 低く、夜間で $1.7 \mathrm{~K}$ 高く、トタン薑き屋根より 昼間で $2.7 \mathrm{~K}$ 低く、夜間で $2.2 \mathrm{~K}$ 高い。これは草蕞き屋根は断熱性が高 いため日射や放射冷却の影響がないが、トタン屋根は日射により表面 温度が上昇し、トタン莫き屋根と石板亘き屋根は夜間放射冷却により 表面温度が低下し、屋根裏付近の気温に影響を及ぼしているためと考 えられる。

\section{6. 温熱環境評俩}

石板莫き住宅の接地階におけるPMV とSET*を算出した ${ }^{18)}$ 。計算にあ たっては、温湿度とグローブ温度は 1 時間平均值を用いた。居住者の 平均的な体格や服装から体重 $55 \mathrm{~kg}$ 、ク口值 $0.8 \mathrm{clo}$ 、代謝量 $1.2 \mathrm{met}$ を想 定した。風速は室内気流が静肃なことから $0.1 \mathrm{~m} / \mathrm{s}$ と仮定した。

図 10 と図 11 に石板晜き住宅の接地階の測定值から求めたPMV と SET* の時刻変化を示す。

PMV の平均は、昼間で-1.1、夜間で-1.3であり、昼夜とも ISO 7730 の 7 段階PMV の推奖範曲士 0.5 末満より低く、「やや寒いと寒いりとい うカテゴリーの間に入る17)。また、SET*の平均は、昼間で $20.4^{\circ} \mathrm{C}$ 、夜 間で $19.6^{\circ} \mathrm{C}$ であり、昼夜とも ASHRAE ST-55 の快適範囲 $22.2 \sim 25.6^{\circ} \mathrm{C}$ より低い15)。昼間は日当たりの良い半外部や外部空間で生活している が、夜間は半外部空間で子供が魅強したり、客とタバコを吸いながら 過ごしたりすることもあり、接地階以外では、蒜然焼がないためPMV、 SET*ともさらに低いと思われる。なお、実際の居住者がどの程度の PMV とSET*で快適と感じるがという主観申告調査は、別報にて明らか にする予定である。

\section{7. 日本の伝統的住宅との此較}

本実測の平均グローブ温度 $\left(19.1^{\circ} \mathrm{C}\right)$ は、アイヌ民族伝統的住居チセ 11)の炉端平均グローブ温度 $\left(29.2^{\circ} \mathrm{C}\right)$ より $10.1 \mathrm{~K}$ 低い。しかし、採暖を 停止している時のグローブ温度は外気温より $5 \mathrm{~K}$ 程高く、本実測のグ ローブ温度の 4. 5K（21:00〜翌朝 5:00の平均）と類似性がある。

表 5 に本実測と 1) 北海道沙流郡平取町二風谷のアイヌ民族伝統住居 11)、2） 5) 山梨県の敷島町、一宮町、河口湖町、山中湖村の木造民家 18、6）岐皁県白川村合掌造り民家 $\left.{ }^{19} 、 7\right)$ 島根県出雲平野の屋数防風林 の木造民家 ${ }^{20)}$ の内外温度差の比較を示す。本実測の外気温は表 5 に 
表 5 ネパールと日本の伝統的住宅の内外温度差(時間平均値)の比較

\begin{tabular}{|c|c|c|c|c|c|c|c|c|c|c|c|c|c|}
\hline \multirow{2}{*}{ 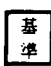 } & \multirow{2}{*}{ 対象研究 } & \multirow{2}{*}{ 住宅程類 } & \multirow{2}{*}{ 分析期閣 } & \multirow{2}{*}{$\begin{aligned} \text { 外気温 } \\
{\left[{ }^{\circ} \mathrm{C}\right] } \\
\end{aligned}$} & \multirow{2}{*}{\multicolumn{6}{|c|}{ 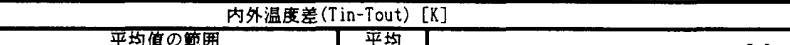 }} & \multirow{2}{*}{\multicolumn{3}{|c|}{ 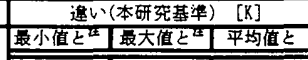 }} \\
\hline & & & & & & 苹均 & & & & {$[\mathrm{k}]$} & & & \\
\hline & 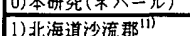 & 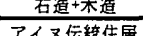 & $\frac{1948.18 .19-20}{1986.12 .23}$ & $\frac{14.0}{38}$ & 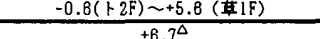 & +1.5 & & & & & & & \\
\hline & 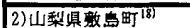 & 木造民家 & 1888.12 & $\frac{-2.8}{8.4}$ & $0.3(\mathrm{t}) \sim 3.5(\mathrm{~b})$ & +1.9 & & 10 & & & $0.9 太$ & 2 215 & $0.4 \pi$ \\
\hline 冬 & 3)山梨䢙一宫町18 & 木造民家 & 1986.12 & 5.0 & $2.0(\mathrm{~b}) \sim 2.1(\mathrm{t})$ & $\overline{+2.1}$ & & & & & $2.8 大$ & $3.5 \mathrm{k}$ & $0.8 大$ \\
\hline 重 & 4)山秋惧河口湖町 18 & 木造民家 & 1986.12 & 3.5 & $1.7(\mathrm{t}) \sim 4.3(\mathrm{~b})$ & +3.0 & & & & & $2.3 大$ & 1.3 小 & $1.5 大$ \\
\hline & 5)山梨貝山中湖村 & 木造民家 & 1986.12 & 3.6 & $-1.1(t) \sim-0.4(b)$ & -0.8 & -1 & & & & 0.5 小 & 6.0 小 & 2.3 小 \\
\hline & 6)岐阜県白川村年 & 合事造り民家 & 1968.12 & 8.4 & 0.0 (ちようだ） 〜+3.8 (台所) & +1.5 & & $\rightarrow$ & & & 0.6 大 & $1.7 \mathrm{k}$ & \pm 0 \\
\hline & 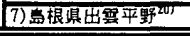 & 木造民家 & $1970.1 .20-2.4$ & $3.7^{\mathbf{2}}$ & $+1.9($ エンガク) 〜+4.3(トカノマ) & +3.0 & & & & & $2.5 \pi$ & 1.3 小 & $1.5 \mathrm{t}$ \\
\hline 類 & 8)山梨具䑤岛町167 & 木道民家 & 1886.4 & 13.5 & $0.6(t) \sim 1.8(b)$ & +1.1 & & tot & & & 1.2 大 & $4.0 \mathrm{~T}$ & $0.4 \mathrm{~T}$ \\
\hline 似 & 9)山梨脜一宮町18 & 木造民家 & 1986.4 & 15.1 & $-0.8(t) \sim 0.1(b)$ & -0.3 & $\infty$ & & & & \pm 0 & 5.5小 & $1.8 \mathrm{~J}$ \\
\hline 外 & 10)山梨逗河口湖町 & 木遗民家 & 1986.5 & 12.6 & $1.3(\mathrm{t}) \sim 2.8(\mathrm{~b})$ & +2.1 & & & & & 1.9 大 & 2.8 小 & $0.6 \mathrm{~A}$ \\
\hline 気 & 11)山梨监山中湖村 & & 1886.5 & 11.8 & $0.8(\mathrm{~b}) \sim 1.1(\mathrm{t})$ & +1.0 & & & & & 1.4 大 & 4.5 小 & 0.5 小 \\
\hline 温 & 12)岐阜置白川村 ${ }^{192}$ & 合掌造り民家 & 1968.4 & 9.4 & -0.6 (ちようだ) 〜+1.7(台所) & +0.5 & $\rightarrow$ & 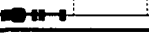 & & & \pm 0 & $3.8 \mathrm{k}$ & 1.0 小 \\
\hline
\end{tabular}

表 6 ネパールと日本の伝統的住宅の団らん時 (暖房時)の上下温度差の比較

\begin{tabular}{|c|c|c|c|c|c|c|c|c|c|c|c|c|c|}
\hline \multirow{2}{*}{ 基 } & \multirow[t]{2}{*}{ 対象研究 } & \multicolumn{2}{|c|}{ 測定位置[回] } & \multirow[t]{2}{*}{ 住宅程類 } & \multirow[t]{2}{*}{ 分析期間 } & \multirow{2}{*}{$\begin{array}{c}\text { 外気温 } \\
{\left[{ }^{\circ}\right]}\end{array}$} & \multicolumn{4}{|c|}{ 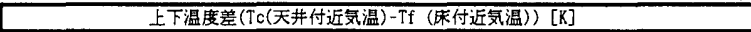 } & \multicolumn{3}{|c|}{ 連い（本研究基率） $[\mathrm{K}]$} \\
\hline & & 下部 & 上暗 & & & & 䉢囲 & 平均 & (1) & 12 & 聂小值と萡 & 晨大值上䒜 & 平均値 \\
\hline & (0)本研究 $(\dot{⿱ 亠 亠 幺 小 ハ ゙ ー ル ゙ ~}$ & 床上0.10 & 天井下 0.10 & 石造+标造 & $1998.12 .19-20$ & 14.0 & 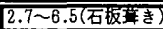 & 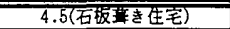 & & & & & \\
\hline 因 & 1)北海道岩胃沢211 & 床上0.10 & 床上 1.80 & 木造 & $1974-1975$ & -10.0 & - & $8.0(\mathrm{Ed}-\mathrm{E} \mathrm{E}) \sim 14.5(\mathrm{H}-\mathrm{N} \mathrm{\textrm {Z }})$ & & & - & - & 3.5 大 $10 大$ \\
\hline 5 & 2)岩手量沢内村 ${ }^{22}$ & 㕅上0.05 & 㕅上 1.00 & 木造 & $1984.1 .31-2.8$ & -6.2 & $8.0 \sim 10.0$ (No.5宅) & - & & & 5.3太 & $3.5 \pi$ & - \\
\hline 時 & 4)奈良顊奈息市 ${ }^{21}$ & 㕅上0.10 & 㕅上 1.00 & 木造 & $0.12 .19-28$ & $5.7^{\Delta}$ & $4.0 \sim 8.0(\mathrm{No}$ 宅 $)$ & -2 & & & $1.3 \mathrm{C}^{2}$ & 0.5 小 & - \\
\hline & 5)京都市 ${ }^{25)}$ & - & - & 町家 & $1882.1 .18-27$ & $4.0^{\infty}$ & - & 3.8 (T宅)、5.0(Y宅) & & & - & - & 0.7 小, 0.5太 \\
\hline & 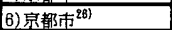 & 床上0.05 & 天井下 0.10 & 町家 & ().冬期 & $4.0^{8}$ & $=$ & $2.9(\mathrm{H}-3$ 宅) $\sim 11.7$ (壮-2宅) & $\bullet$ & & - & - & 1.6小 7.2大 \\
\hline
\end{tabular}

あげた分析期間の外気温より $7.6 〜 16.8^{\circ} \mathrm{C}$ 高いため、本研究の外気温 と同じレベルになるように、8)〜 12) では日本の 4、5月の外気温を用 いて内外温度差を検討した。しかし、8）～12）の内外温度差は1)〜 7)の冬季よりも小さい。ネパールと日本の外気温のレベルは異なって いるが、暖房期の使用状況をそろえるために、1)〜 7)の冬季(暖房期) という条件で比較する方が妥当と判断した。内外温度差は、1） 7) の各調査における最も差の小さい部屋と比較すると、0.6(岐阜県白川 村)〜 2. $6 \mathrm{~K}$ (山梨県一宮町) 大きい。また、各調查における最も差の大 きい部屋と比較すると、1.3 (山梨県河口湖町、島根県出雲平野) 3. $5 \mathrm{~K}$ (山梨県一宮町) 小さい。更に、各調査における部屋間平均值と比 較すると、0.0 (岐阜県白川村) 1.5K（山梨県河口湖町、島根県出雲 平野) 大きい。ただし、5）山梨県山中湖村は除いた。日本の1）～7） 調査の内外温度差は本研究の温度差の範囲に入っている。2) 4) は 寝室と便所の 2 所のみの調查であるので、内外温度差の平均值は本 実測より高め(最大 $1.5 \mathrm{~K}$ )に出ている。しかし、6)のように本実測と同 様に一戸の住宅の各部屋で測定した例と比較すると、外気温度のレ ベルが異なるにも関わらず、内外温度差の平均值が殆ど一致(1.5K) ている事実は注目に值する。7)は防風林の効果で高めに出たと思われ る。日本との内外温度差の違いは量的に僅かであり、伝統的住宅の 熱的性能は類似しているといえる。

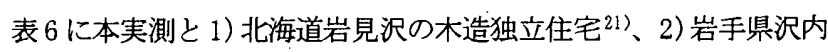

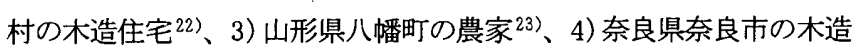

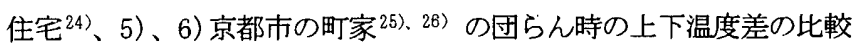
を示す。文献により測定高さは異なるが、上下温度差は、本実測(平 均 $45 \mathrm{~K}$ ) より北海道岩見沢市で $3.5 \sim 10 \mathrm{~K}$ 大きく、京都市町家で $1.6 \mathrm{~K}$ 小 さい〜 7.2K 大きい。上下温度差の範囲は、本実測 $(2.7 \sim 6.5 \mathrm{~K})$ 上り岩 手県沢内村、山形県八幡町、奈良県奈良市で $1.3 K \sim 8.5 K$ 大きい。日 本の住宅の団らん時平均の上下温度差は、本実測より最大で $10 \mathrm{~K}$ 大き く、暖房方法、採暖習慣、外気温のレベルによる違いと考えられる。

\section{8. 考察}

接地階 / 中間階と屋根裹の内外温湿度差、上下温度差の差異は、接 地階 / 中間階ではドアや空開閉、薪燃焼などの生活習慣と開口部の
少ない閉鎖的空間構成の熱的性能から生じ、屋根裏のそれらは開口 部の多い開放的な空間構成、石板莫き・草蕞き・トタン莫きの屋根 素材の熱的性能から生じたと考えられる。接地階/中間階の温湿度 は、昼間は外部の影響が、朝晚の時間帯は薪燃焼の影響が大きく、屋 根裏は昼夜とも外部の影響が大きい。接地階 / 中間階の内外温湿度 差、上下温度差は屋根裏より大きいことから、接地階/中間階の温熱 環境は屋根裏より良好であると言える。草莫き屋根は日射や夜間放 射冷却の影響がないが、トタン莫き屋根は日射の、トタン荣き屋根 と石板葛き屋根は夜間放射冷却の影響があることから、屋根裏の温 熱環境に建物間で差が生じ、草蕞き屋根の性能が良く、トタン蕞き 屋根の性能が劣っている。石板葺き屋根の温度変動が昼間は草荤き 屋根に近いが、夜間はトタン蕒き屋根に近いことから、石板莫き屋 根の性能は草草き屋根とトタン亘き屋根の中間にあるといえる。ま た、PMV は推奨範囲より、SET*は快適範囲より低いことから、ネパー ル山岳地帯の人々は熱的快適範囲より低い伝統的住宅で生活してい るといえる。一般的にいわれている熱的快適範囲より低い温熱噮境 ではあるが、彼らは昼間に寒ければ日光を浴び、暑ければ日陰に移 動し、夜間に寒ければ薪で暖を取って、温熱環境を調整する。更に、 ネパールと日本の住宅を暖房期 (冬季)で比較すると、外気温のレベル が異なるにも関わらず、内外温度差はともに $1.5 \sim 3.0 \mathrm{~K}$ と類似して いた。日本のほとんど住宅の上下温度差はネパールより大きく、ほ とんどがASHRAE ST-55 の推奨值を超えている。

\section{9. 改善案}

ネパール山岳地帯の人々の住み方は自然共生的ではあるが、開放 されたままの開口部や断熱されていない屋根は、朝晚と夜間の寒い 時間帯に冷気浸入や熱流出に慗がっていると考えられる。また、冬 季の寒さを緩和するために大量の薪を消費しているが、近年薪量の 確保が困難になっている理由で、薪消費削減が急務となっている。更 に、薪燃焼から発生する煙が居住者の健康に悪影響を与えていると 思われる。快適な温熱環境を実現し、しかも環境やエネルギー負荷 の少ない（薪消費削減）、健康的な住宅（排煙）を実現するために、 社会、経済、㻴境的にネパールで実現可能な以下の改善案を示す。 
(1) 開口部改善による気密化 : 戸や空は、現状では常に開放されてい るが、戸を付けて夜間に閉じられるようにする。

（2）屋根改善による断熱化 : 石板莫き屋根とトタン蒙き屋根は断熱性 のある材料を設けておらず、屋根に木材と粘土層を設ける。これは 従来の天井構法を屋根構法に応用したものである。

(3) 階段吹抜改善による上下階の分離 : 階段吹抜からの熱流出や泠気 侵入を防ぐために夜間に階段吹抜を木板で塞ぐ。これは約 20 年前ま で伝統的住宅にあった形態を再考したものである。

(4) 間仕切りによる室内空間の分割 : 室内の入口や階段付近は半外部 的になっているため、暖を取る空間を間仕切で分割する。

(5) 熱の有效利用による薪消費削減 : 薪然焼からの発生熱を建築部位 に蓄熱する。

（6）炬改善による排煙 : 現状では開放型炉が使用されており、薪から 発生する煙を処理する煙乫付きの半密閉型炬を設ける。

なお、これらの改善案の定量的効果はシミュレーションで検証し、 別報にて明らかにする予定である。

\section{0. 結論}

ネパール山岳地帯における伝統的住宅の温熱環境の評価と改善を 目指して、冬季の温熱環境実測を行い、外部噮境と住宅計画の関係、 内外温湿度差、上下温度差、PM、SET*、日本の伝統的住宅との比較、 改善の方向性について、以下のことを明らかにした。

1）正面である南側の前庭、東と南側の半外部空間は昼間の日照の 確保に、南側の開口部配置は昼間の南からの温風の室内導入に、 北側と東西側の石造壁は夜間の北からの冷気侵入の防止に役 立っている。

2）接地階/中間階における平均内外温度差（内-外）は昼間 $+2.5 K$ 、 夜間 $+4.7 \mathrm{~K}$ 、平均内外絶対湿度差 (内一外) は昼間 $+0.9 \mathrm{~g} / \mathrm{kg}$ ，夜 間 $+1.2 \mathrm{~g} / \mathrm{kg}$ 、平均上下温度差 (上-下) は昼間 $+3.7 \mathrm{~K}$ 、夜間 $+28 \mathrm{~K}$ であり、内外の差が殆どない屋根裏より昼夜とも大きいことか ら、接地階/中間階の温熱環境は屋根裏より良好である。しか し、接地階の平均上下温度差は、炉付近で昼間 $+3.2 \mathrm{~K} 、 入 り 口$ 付近で昼間 $+4.2 \mathrm{~K}$ 、夜間 $+4.0 \mathrm{~K}$ であり、ASHRAE ST-55 の推奨値の $3 \mathrm{~K}$ より大きく、薪で発生する熱の浪費を示唆している。

3）草莫き屋根は日射や夜間放射冷却の影響がないが、トタン莫き 屋根と石板莫き屋根には日射や放射冷却の影響がみられ、草莫 き屋根の性能が良く、トタン蒙き屋根の性能が劣り、石板草き 屋根の性能は両者の中間にあった。

4）日平均PMV は-1.2であり、ISO 7730 の推奖範囲士 0.5 より低い。

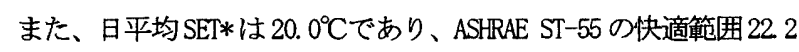
〜25. $6^{\circ} \mathrm{C}$ より低い。ネパール山岳地帯の人々は一般にいわれて いる温熱的快適籁囲より低温で生活していた。

5）ネパールと日本の住宅の平均内外温度差は暖房期で比較する と、ともに $1.5 \sim 3.0 \mathrm{~K}$ であった。日本の住宅の団らん時(暖房 時)の平均上下温度差の方が、本実測より最大 $10 \mathrm{~K}$ 大きかった。

6）快適な温熱環境を実現し、しかも環境やエネルギ一負荷の少な い（薪消費削減）、健康的住宅（排煙）を実現するために、開 口部改善による気密化、屋根改善による断熱化、階段吹抜改善 による上下階の分離、間仕切による室内空間の分割、熱の有効 利用による薪消費削减、炉改善による排煙を提案した。
解辞

図面の実測に芝浦工業大学・畑研究室の方々に多大なご協力を頂いた。ここに記し、 韵意を表す。

\section{本諳文に関する既発表論文}

a） H. B. リジャル、吉田治典、梅宮典子 : 環境形能デザインの手法 ネパールの温 爱地域に拈ける层統的な集落の温熱環境、日本建策学会近畿支部研究報告集 (環境系)、第 39 号、pp. 25-28、1999.6

b) H. B. リジャル、吉田治典、梅宮典子：ネパールの伝統的住居の「環境形態」の 分析と提案、日本建策学会大会学術講演梗概集 (中国)、D-1、pp. 1081-1082、1999.

注

注 1）空間構成、構法は伝統的であるが、近年トタン屋根を使用する住宅もあり、検 即対象とした。

注 2) 新は唯一のエネルキー源であり、一年を通じて調理、暧房、照明（電灯照明 がない，家畜の食料の加工に利用されている。ネパールでは、ストーブでは なく薪を燃やして裸火を使用している。冬季の朝晚に薪を然やして暖をとる。 しかし、薪から発生した煙は空内に充満し、開口を経て上部階へも伝播する。 近年は新不足が深刻になっているため、村の役所が暗可鲫囲内で伐採を行わ せている。

注 3）トタン屋根は、施工性、耐久性、成金趉味的流行から、最近 20 年来、草草き 住宅の代わりに、近代的材料として普及しつつある。トタン屋根は、夏季は 暑く冬季は寒く、雨や琶が跭ると船音も大きいが、值段が安価なため利用者 は多い。

注 4）村にはヒンドゥー教の生活習慣を持つブラマン族、チェトリ族、バイセ族、ス ドラ族が住んでいる。村人は山の梦からほほ頂上まで斜面を切り開いて段々 畑を作り、家畜を䬼い、自給自足の生活をしている。このような社会椪造、ラ イフスタイルはネパール山岳地帯の広笔囲にわたる代表的なものである。

\section{参考文南} 1) Gerard Toffin Edited: Man and His House in the Himalayas, Sterling Publishers, 1991.
2) (社) 日本ネパール協会編 : ネパールの集落、古今書院、1992.

3）芝浦工業大学・烟研究室、H. B. リジャル、栗原宏光：特集 ネパールヒンドゥー 教が山中に描く集落世界、住宅建筑、pp. 30-73、1997 年 3 月号

4） H B 、リジャル、中村奏人、吉田治典：環境共生建筑のモデル化 ネパール山岳 地帯の自然環境に調和した伝統的な民家に関する考察、日本建築学会、第 2 回アジアの建筑交流国際シンポジウム論文集、pp. 381-384、1998.9.

5）黑津高行、渡辺勝彦: チョク建筑の構造 ネパールの王宮における中庭建筑の 研究 その 1、日本建筑学会計画系論文報告集、第 408 号、pp. 101-109、1990.2.

6）モハン パント、布野修司 : Spatial Structure of the Jyapu Community Quarters of the City of Patan, Kathmandu Valley、日本建策学会㖕画系論文集、第 527 号、pp. 177184、2000.1.

7）木村健一編著：民家の自然エネルキー技術、彰国社、1999

8) 浦野良美、渡边俊行、林徹夫、内山明彦：九州北部に残る伝統的民家の熱環 境に関する調査研究、日本建築学会計画系論文報告集、第 371 号、pp. 27-37、 1987.1.

9）宇野勇治、堀越哲美、宮本征一、横山尚平：中部日本の山間部における伝統 的住宅の室内気侯調節と立地集落の微気侯、日本建策学会計画系論文集、第 532 号、pp. 93-100、2000.6.

10）花岡利昌著 : 伝統的民家の生㸃学、海青社、pp. 147-168、1991

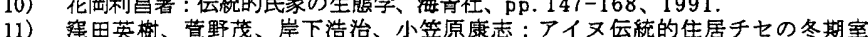
内環境、空気嗰和・衛生工学会論文集、No. 41、pp. 1-10、1989.10.

12) H.M.G National Planning Commission Secretariat, CBS, Kathmandu, Nepal: A Compendium on Environment Statistics 1998 Nepal, pp. 20, 1998.5

13) Ram Kumar Pandy: Development Disorders in the Himalayan Heights Challenges and Strategies for Environment and Development Altitude Geography, pp. 53,203,290, 1995.

14) H.M.G. of Nepal, Ministry of Science and Technology Department of Hydrology and Meterology, Kathmandu: Climatological Records of Nepal, 1991-1994, 1997.

15) Thermal Environmental Conditions for Human Occupancy, ASHRAE Standard, ANSI ASHRAE 55-1992,1992.

16) Marc E. Fountain, Charles Huizenga: ASHRAE Thermal Comfort Tool, ASHRAE Research Project 781-RP, Environmental Analytics of Berkeley, Califomia, 1997.

17) Moderate Thermal Environments Determination of the PMV and PPD Indicesand Specification of the Conditions for Thermal Comfort, ISO $7730,1994$.

18）宮野則彦、浅見雅子、宮野秋彦:誛室及び便所の温湿度変化から見た居住環 境の考察 山梨累下の伝統的木造民家を对象として、日生気誌、27(2)，pp.57一 70、1990.

19）梁瀬度子、今村史子、市川啓子、花岡利昌 : 民家の微気候学的研究 第 4 報岐 阜県白川村合掌造り民家の室内気候について、家政学研究、Vol.16 No.1.2、 pp. 64-73、1969. 12.

20）五十嵐由利子、梁瀬度子、花岡利昌：民家の微気候学的研究 第 7 報出罢平 野における屋敷防風林の室内気侯に及ほす影響について、家政学研究、V 01.18 No. 2, pp. 53-59,1971.12

21）絵内正道、荒谷登 : 住居室の温热環境の実熊、その1、その2、日本建策学会 論文報告集、第264号、第265 号、pp.91-97、pp. 105-113、1978.2、1978.3.

22）牧田一志、長谷川房雄、吉野博、赤林伸一、菊田道宣: 東北地方住宅にお ける温熟環境調査、その 18、日本建策学会東北支部研究発表会、pp.111-116、 1985.11.

23）菊田道宣、長谷川房雄、吉野博、赤林伸一：東北地方の住宅における温熱環 境調查、その16、日本建策学会東北支部研究発表会、pp.209-212、1983.11.

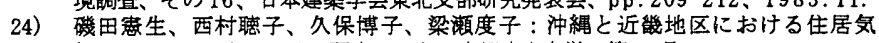
候について、ハウスクリマ研究ノ一ト、京都府立大学、第 17 号、pp. 9-20、1991.6.

25）松田彰、翁長博、松原亦樹：京都における低層密住市街地住宅の温就環境に 関寸る研究、日本建策学会近畿支部研究報告集、pp. 53-56、1982.6.

26）松原斎樹、澤島智明：冬期の住宅居間の熱環境について、ハウスクリマ研究 ノート、京都府立大学、第 18 号、p p. 1-8、1992.6.

(2000年 9 月 7 日原稿受理, 2001 年 3 月 15 日採用決定） 